\title{
THE EFFECT OF CAPITAL ALLOCATIONS ON ECONOMIC GROWTH, HUMAN DEVELOPMENT INDEX AND POVERTY IN NORTH MALUKU OF INDONESIA DURING 2010-2016
}

\author{
Umsohy M. Iksan*, Ananda Candra Fajri, Wahyudi Setyo Tri \\ Faculty of Economics and Business, University of Brawijaya, Indonesia \\ *E-mail: muhammadiksan13@gmail.com
}

\begin{abstract}
This study aims to test and analyze: influence of Capital Expenditure Allocation to Economic Growth; influence of Allocation of Capital Expenditure and Economic Growth to Human Development Index; influence of Capital Expenditure Allocation; Economic Growth and Human Development Index to Poverty in Districts / Cities in North Maluku Province. The research method used is panel data regression. The results of this research founded that model 1 influence of Capital Expenditure Allocation have significant influence to Economic Growth. Model 2 Capital Expenditure Allocation has a positive but insignificant influence on the Human Development Index even though the increase is not significant while Economic Growth has positive and significant effect on Human Development Index while model 3 allocation of Capital Expenditure has positive and significant influence to Poverty. While Economic Growth has a negative impact on Poverty, Furthermore, Human Development Index as an indicator of strengthening of human resources has a negative and significant influence on Poverty level in 9 regencies of North Maluku Province.
\end{abstract}

\section{KEY WORDS}

Capital expenditure, growth, human development index, poverty.

Regional development is an integral part of development national implementation based on the principle of regional autonomy and regulation of national resources that provides an opportunity for democratic enhancement and regional performance in establishing a partnership pattern between local government and private sector to create a new job field in order to improve the welfare of the community. Yani, (2002) reveals that one of the affairs given to the region is the income-generating business to the Regional Government and various potentials to be developed in the excavation of new sources of income for the region concerned. In relation to regional development, efforts to realize the successful implementation of fiscal policy of economic development in an area are highly dependent on the quality of development planning in promoting economic growth and human development index (HDI) and in suppressing poverty.

Tamboto, et al. (2014) 'Analysis of Local Financial Capability in the Period of Regional Autonomy in Southeast Minahasa District' expected to provide wider empowerment for regions to improve their financial performance and optimize their local potentials so that in turn the local financial capacity becomes better and the regions become more independent. This is in line with the enactment of Indonesia's Law no. 32 of 2004 and Law No. 33 of 2004 on the financial balance between central government and local government is a reform of relations between the central government and local governments. Given the delegation of authority is expected that the regions will be able to perform routine tasks, public services and improve the productive economy in the region.

One of the most important factors for determining fiscal decentralization is the extent to which local governments are authorized to determine allocations for their own expenditures. So that with the allocation of allocations for regional expenditure is believed to contribute to economic growth or all aspects of the economy that ultimately can reduce the poverty level.

The form of government expenditure is one of them is the allocation of capital expenditure in order to provide public facilities that can be a fixed asset area and has a value of more benefits is expected to be a supporting capital in improving the implementation of 
various economic activities of the community. In an effort to improve the economythe government through appropriate allocation of capital expenditure by taking into account the scale of priorities and needs of the regionwhich optimally synergize with other expenditure allocations. It is expected to create jobs for the community through a program of development activities that are implemented annually so as to increase the production capacity of goods and services in various activities of economic activities of the community that impact on regional economic growth

This is in line with various studies on capital expenditures made by. Danladi et al (2015) Resulting that the increase in total government spending by capital and expenditures is continuous, the results show that all are positively related to economic growth. While Nurudeen and Usman (2010) resulted that capital expenditure negatively affects economic growth in Nigeria. However, different results were also found by Hamsinah, et al. (2014) conclude that capital spending has no effect on economic growth in South Sulawesi Province.

The paradigm that develops today is that economic development is measured by human development which is seen from the quality of human resources owned. The link between capital expenditure and the Human Development Index is very closely linked to government policies to improve the quality of human resources. This is also in line with research conducted by Sasana (2012) that the realization of regional spending has a positive and significant impact on the Human Development Index. While research Sumiyati (2009) shows capital expenditure has a positive and insignificant influence on the increase Human Development Index. This means that local government expenditure is also intended for education and health services which are the basic services that must be obtained by the community such as the procurement of regional infrastructure and adequate public facilities will improve the quality and quantity as well as improve local productivity, community income, and increase the Human Development Index (HDI).

One strategy to reduce the poverty rate is the development of Human Resources (HR). Human resource development can be done by improving access to the consumption of social services (education, health and nutrition). The decline in poverty levels is inseparable from the role and efforts of the government in alleviating poverty through policies and programs applied to various elements, both central and local governments. Overcoming poverty can not be done separately from other problems.

North Maluku Province is one of the provinces located in eastern Indonesia which has a long history of slow development process resulting from horizontal conflict in 1999. As a result of this conflict impacted on all matters not only occur in the aspect of the regional economy but one of them is public facilities and public services in various districts I municipalities in North Maluku Province. With regard to public services, the allocation of capital expenditure is very important to note as it will increase the productivity of the regional economy.

The allocation of capital expenditures issued based on the needs of the region for the smoothness of facilities and infrastructure that is public facilities, as well as the implementation of government duties. Therefore, in the effort to improve the quality of public services, local governments are required to change the composition of their capital expenditure. North Maluku Province continues to grow with the addition of new autonomous regions so the birth of new districts with the average development of capital expenditure allocation in APBD during the period 2010-2015 varies from year to year can be seen in Figure 1 These changes are subject to local development policies adopted.

Average development of city government capital expenditure allocation in Province North Maluku outside Taliabu Island Regency due to new expansion in 2013, can be seen in Figure 1 shows the average allocation of district / municipality capital expenditure in North Maluku Province shows the fluctuation from 2010 to 2013. Fluctuating

capital expenditure allocation can show the implementation of expenditure program of APBD capital expenditure has not been done well because not only in financing of employee facility but also the provision of various public facilities such as infrastructure so as to impact on the improvement of economic activities of the community. Should change the composition 
of APBD expenditure for capital expenditure needs to encourage the regional economy needs to be done because the greater allocation of capital expenditure is expected to have a great impact on regional economic growth. Because capital expenditure is productive government expenditure and can be used to boost economic growth and increase the Human Development Index (HDI) in the regions, which in turn is expected to reduce poverty levels.

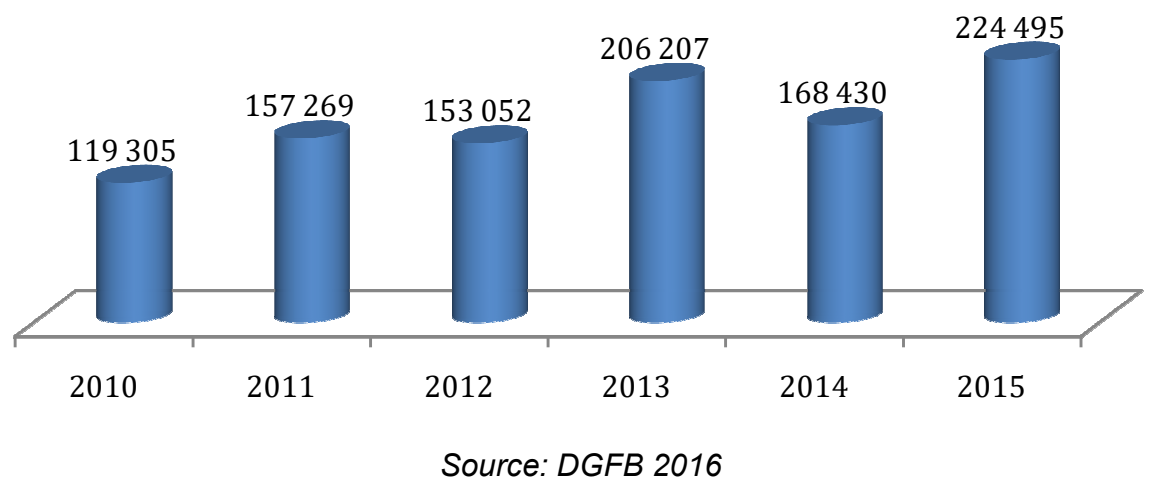

Figure 1 - Average Local Capital Expenditure Allocation Regency of North Maluku Province Year 2010-2015 (in Million Rupiah)

Regional economic growth as measured by the size of GRDP per capita in Kota District in North Maluku Province during 2010-2016 period tends to increase can be seen in Figure 2.

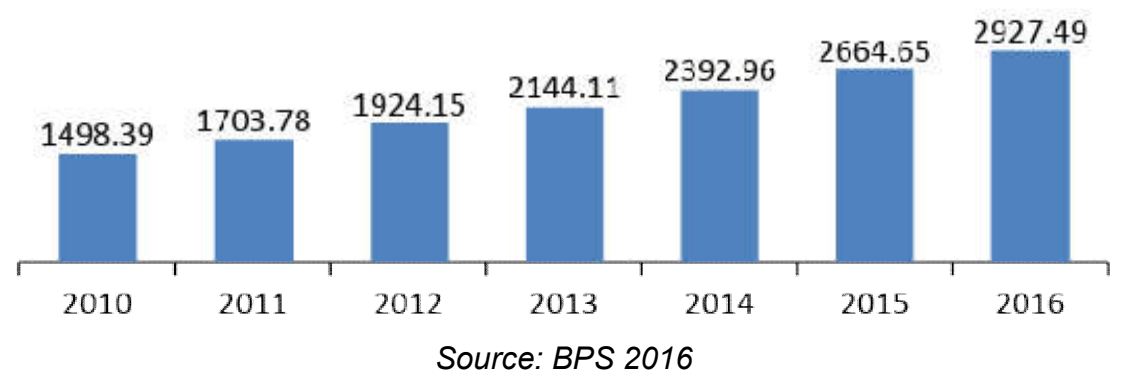

Figure 2 - Average GRDP with Upper Oil and Gas Basic Constant Price of 2000, District Cities in North Maluku Province Year 2010-2016 (billions)

Economic growth is one of the important indicators in conducting an analysis of economic development in an area. Based on Figure 2 above, can be seen that Performance of regional economic growth as measured from the average GDP of Regency / City in North Maluku Provinceduring the period 2010-2016 tends to increase. In 2010 the average GRDP of regencies / cities in North Maluku Province amounted to IDR 1498.39 mliyar and in 2011 increased to IDR 1703.78 in 2012-2013 again increased to IDR 1924.15 billion, 2144.11 billion. Then in the Year 2014-2015 increased to IDR 2392.96 billion, 2664.64 billion and in 2016 the average GDP of districts / cities in Maluku Province Utarah reached IDR 2927.49 billion.

When viewed from the economic growth of districts / cities on average have a relatively increased growth. This is consistent with that of Leasiwa (2016) that high and sustainable economic growth is a key condition for economic development. However, what is expected is whether through a larger allocation of capital expenditure can continue to increase economic growth and will drive the economic activities of society at every district / city, so as to encourage economic growth in the areas concerned and reduce the level of poverty.

Quality human resources are essential in supporting the expansion of regional economic development. The more quality of human resources in the region, it will increase 
the growth in a sustainable and improved. The following is the average Quality of regency/ municipal human resourcesin North Maluku shown through the HDI value in Figure 3.

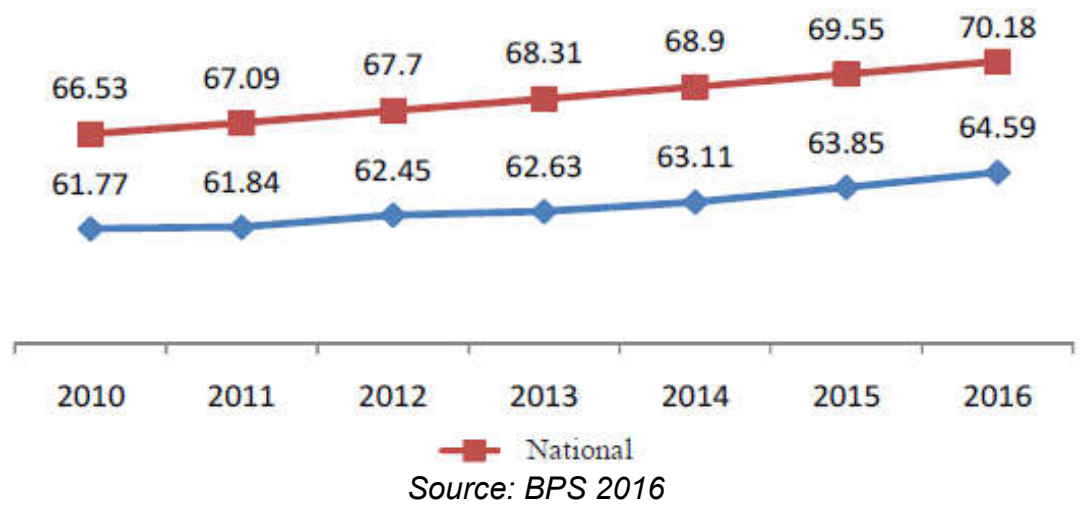

Figure 3 - Average Human Development Index (HDI) District of City in North Maluku Province and National, Year 2010-2016 (\%)

Based on the Average Human Development Index (HDI) shown in Figure 3 above shows Factually the index of human development of North Maluku Province in 2010-2016 tends to increase as the trend ratio nationally, but HDI District District in North Maluku Province still in the middle category and achievement is still lower than the achievement of national HDI this indicates that North Maluku province has not plays a strong role as a driver to improve the welfare of the national community, even tend to become a national burden.

This requires the role of local governments in exploring the performance of regional development policies through the implementation of capital expenditure allocations with appropriate programs and in various sectors such as the education sector, income generation which will then affect the improvement of human development index and reduce poverty level.

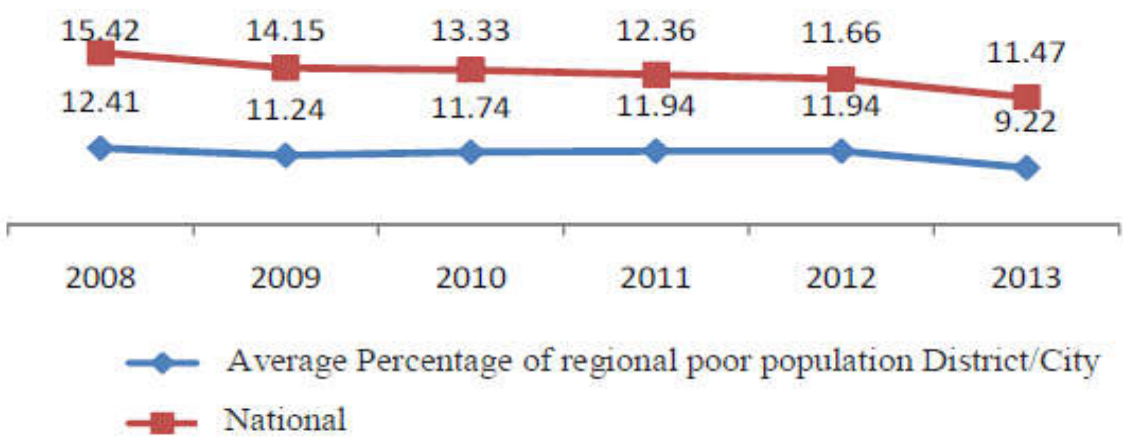

Source: BPS 2016

Figure 4 - Average Percentage of regional poor population District / City in North Maluku Province and National, Year 2008-2013 (\%)

As for the average Development Percentage Poor people in City District in North Maluku Province can be seen in Figure 4 In 2008 the average Poor population of districts/municipalities in the Province of North Maluku amounted to 12.41 percent and in 2009 decreased to 11.24 percent Then in 2010 increased to 11.75 percent in the next year 2011-2012 again experience increased to 11.94 percent and in 2013 decreased to 9.22 percent. Meanwhile, the percentage of the national poor continues to decline.

Average Percentage of Poor District/Municipality in North Maluku Province from year to year fluctuates so that some programs are needed to minimize the fluctuation rate. Poverty can make a serious enough effect for human development as well as economic growth because poverty is a complex issue. If you look at the condition of the development of capital expenditure allocation, the economic growth and human development index of the North 
Maluku City district continue to fluctuate and the difference between the research results between the variables studied so that the fundamental question that needs to be developed for the change is how far the government spending in capital expenditure allocation can increase economic performance of autonomous regions as a whole and able to increase economic growth, Human Development Index (HDI) and reduce the poverty level that ultimately for the improvement of people's welfare.

Therefore, this study aims to investigate:

- The Effect of capital expenditure allocations on economic growth

- The influence of capital expenditure allocation and economic growth on HDI.

- Influence of capital expenditure allocation, economic growth and HDI to poverty.

\section{METHODS OF RESEARCH}

The approach to this research is quantitative research. The type of data used in this study is secondary data using pooled data panel data by combining cross section and time series data, 9 districts/cities in North Maluku Province during the period 2010-2016. Where Secondary data source obtained from Directorate General of Fiscal Balance Ministry of Finance (DJPK) and Central Bureau of Statistics (BPS) Province of North Maluku

Equation model used in this research are:

a. The model ofdata equation cross section and time series is the effect of capital expenditure on economic growth:

$$
\begin{gathered}
P E=\alpha+\beta_{1} A M B_{i t}+\varepsilon_{i t}, \\
i=1.2 \ldots \ldots N ; t=1.2 \ldots . . T
\end{gathered}
$$

b. The data model of cross section and time series is the effect of capital expenditure on economic growth and human development index (IPM):

$$
\begin{gathered}
I P M=\alpha+\beta_{1} A M B+\beta_{2} P E+\varepsilon_{\text {it }} \\
i=1.2 \ldots \ldots . N ; t=1.2 \ldots \ldots . T
\end{gathered}
$$

c. The model of cross section and time series data equation is the influence of capital expenditure, economic growth and human development index (HDI) on poverty:

$$
\begin{aligned}
\text { Poverty }= & \alpha+\beta_{1} A_{M B} B_{i t}+\beta_{2} P E_{i t}+\beta_{3} I P M_{i t}+\varepsilon_{i t} \\
& i=1 \ldots \ldots . N ; t=1.2 \ldots . . T
\end{aligned}
$$

Where:

AMB = Allocation of capital expenditure;

$\mathrm{PE}=$ Economic growth;

$\mathrm{HDI}=$ Human development index;

Poverty = Poverty;

$\alpha=$ Coefficient of constant;

$\beta=$ Regression coefficient of independent variable;

$\varepsilon=$ Error;

$\mathrm{i}=$ Regency / City I;

$\mathrm{t}=$ Period $\mathrm{t}$.

\section{RESULTS AND DISCUSSION}

The overall model is estimated using the reviews program with the following model specifications:

Regression Panel Data Test Result with Method Fixed Effect model 1the influence of capital expenditure allocation on economic growth. Result of model 2 test of influence of capital expenditure allocation and economic growth on index of human development. Result 
of model 3 test of influence of capital expenditure allocation, economic growth and index of human development to poverty can be seen through Figure 5 below.

Figure 5 - Calculation Result Estimation with Panel Data

\begin{tabular}{|c|c|c|c|c|c|c|c|c|c|}
\hline \multirow{3}{*}{ Variabel } & \multicolumn{3}{|l|}{ Model 1} & \multicolumn{3}{|l|}{ Model 2} & \multicolumn{3}{|c|}{ Model 3} \\
\hline & \multicolumn{3}{|l|}{ Growth } & \multicolumn{3}{|l|}{$\mathrm{HDI}$} & \multicolumn{3}{|c|}{ Poverty } \\
\hline & Coeff & t-sta & orob & Coeff & t-statis & prob & Coeff & t-statis & prob \\
\hline $\mathrm{ABM}$ & 0.491 & 3.941 & 0.007 & 0.001 & 0.070 & $0.944^{*}$ & 0.099 & 1.682 & $0.099^{*}$ \\
\hline Growth & - & - & - & 0.099 & 7.989 & 0.000 & -0.670 & -4.666 & 0.000 \\
\hline $\mathrm{HDI}$ & - & - & - & - & - & - & -0.661 & -0.611 & 0.544 \\
\hline C & 1.684 &. .831 & 0.000 & 3.387 & 59.097 & 0.000 & 8.856 & 2.399 & 0.020 \\
\hline Fixed Effect (Cross) & & & & & & & & & \\
\hline KAB_HAL_BAR-C & -0.208 & & & 0.019 & & & -0.048 & & \\
\hline KAB $\mathrm{HAL}^{-}$TEN-C & -0.534 & & & 0.006 & & & -0.403 & & \\
\hline KAB_KEP_SUL-C & -0.353 & & & -0.043 & & & 0.041 & & \\
\hline _KAB_HAL_SEL-C & 0.361 & & & -0.093 & & & 0.616 & & \\
\hline -KAB_HAL_UT-C & 0.462 & & & -0.039 & & & 0.490 & & \\
\hline${ }^{-} \mathrm{BAB}^{-} \mathrm{HAL}^{-} \mathrm{TIM}-\mathrm{C}$ & -0.104 & & & -0.010 & & & 0.393 & & \\
\hline KAB_P_MOR-C & -0.767 & & & -0.006 & & & -1.158 & & \\
\hline KOTA_TERNAT-C & 1.146 & & & 0.097 & & & 0.600 & & \\
\hline _KOTA_TIDORE-C & -0.002 & & & 0.069 & & & -0.531 & & \\
\hline R-squared & 0.955 & & & 0.983 & & & 0.947 & & \\
\hline Adjusted R-square & 0.947 & & & 0.979 & & & 0.936 & & \\
\hline F-statistic & 124.085 & & & 292.435 & & & 82.942 & & \\
\hline Prob(F-statistic) & 0.000 & & & 0.000 & & & 0.000 & & \\
\hline
\end{tabular}

* Not significant processed data, (2018).

Influence of Regional Capital Expenditure Allocation to Economic Growth. Capital expenditure allocation formed from expenditure the government allocated for investment in public sectors is expected to trigger economic growth, and directly in contact with the interests of the public or society in the region.

Regression equation from result of regression panel data analysis estimation in general equal to 1.684 indicates that if capital expenditure allocation and economic growth have constant value (unchanged) hence economic growth Regency of North Maluku Province is $1.684 \%$. With the value of capital expenditure allocation coefficient is 0.491 indicates that the allocation of capital expenditure has a positive effect on economic growth. This shows an increase in capital expenditure allocation of $1 \%$ will increase economic growth in the Regency / City of North Maluku Province increased by $0.491 \%$.

Based on the results of regression analysis panel data illustrates that the allocation of capital expenditure (ABM) gives a positive impact on economic growth in North Maluku province but if seen from per city districts separately showed still relatively low even negative as happened in morotai island district, middle halmahera, sula islands, and western halmahera from these results so that the government is expected to increase the allocation of capital expenditure not only to help smooth the task of government but with the aim of improving public facilities so that by itself can give effect to regional economic growth, this is also supported by the endogenous growth theory which, according to Barro and Sala-i-Martin (2004), states that productive government spending, positively correlated to economic growth. From the results of this study the same as the research conducted byNopiani, et al. (2016) Whereas capital expenditure variable has positive effect to economic growth, it shows that capital expenditure play a direct role in the effort to increase economic growth. Findings in accordance with Keynesian theory, public expenditure can in itself provide positive results for economic growth.

The Influence of Capital Expenditure Allocation and Economic Growth To Human Development Index. Refers to the result of regression analysis of panel data illustrates that capital expenditure allocation (ABM) gives positive impact to human development index and 
economic growth also have positive and significant influence to Human Development Index in Regency / City of Province North Maluku.

Regression equation from result of estimation of regression analysis of panel data in general equal to 3.387 indicates that if capital expenditure allocation and economic growth have constant value (unchanged), hence index of human development of Regency of North Maluku Province 3.387\%.

Furthermore, the regression coefficient of capital expenditure allocation variables and economic growth, the value of capital expenditure allocation coefficient is 0.001 indicating that capital expenditure allocation has positive and insignificant effect on human development index. this shows that the allocation of capital expenditure is almost partly only in the financing of equipment for the implementation of government tasks so that the allocation of capital expenditure funds, especially in the field of education is reduced, which should be expected to be greater for regional progress and educate the children of the region by means of building construction, adequate for school comfort.

This is in line with research Sasana (2012) that the realization of regional spending has a positive and significant impact on HDI in Central Java.Nor Zebua (2014) shows that Capital Expenditures affecting HDI with a positive and significant direction.

While the economic growth coefficient of 0.099 indicates that economic growth has a positive and significant effect on the human development index. This is the same as expressed by Ranis (2004), mentioning that economic growth has a direct impact on human development improvement through income generation. Increased revenues will increase the allocation of household spending for healthier food and better education. With the increasing of economic growth hence will increase of income per capita of society so that HDI in one region also also increase. Economy, is the greater the human development index.

Effect of Capital Expenditure Allocation, Economic Growth and Human Development Index on Poverty. Based on the result of regression analysis, panel data illustrates that Capital Expenditure Allocation (ABM), Economic growth and human development index have an effect on poverty in Regency / Municipality of North Maluku Province.

Regression equation from result of estimation of regression analysis of panel data in general equal to 8.856 indicate that if allocation of capital expenditure, economic growth and index of human development have constant value (unchanged) hence poverty of Regency of North Maluku Province equal to $8.856 \%$.

Furthermore, the regression coefficient of capital expenditure allocation variables of economic growth and human development index, the value of capital expenditure allocation coefficient is 0.099 indicating that the allocation of capital expenditure has positive effect on poverty And not significant to poverty. This means that an increase in capital expenditure allocation of $1 \%$ will increase poverty by $0.099 \%$, although the increase is not significant. This indicates that the allocation of capital expenditure does not directly affect the poverty but through economic growth and HDI can contribute to the decline in poverty.

While the economic growth coefficient is -0.670 indicates that economic growth has a negative and significant impact onpoverty.

According Kuznet (2001) relationship between economic growth with the level of poverty has a very strong correlation This is in accordance with the existing theory apabilah economic growth increases the income of the community increases so that will affect the poverty that decreases. This is in accordance with research conducted by Faturrohim (2011) whereas the GRDP variable has a negative and significant effect on the poverty rate in Central Java. Also in line with the research undertaken by Ingka (2014) the result of research is the variable of economic growth has a negative and significant effect on poverty level in South Sulawesi Province

While the coefficient of human development index is -0.661 indicates that HDI has a negative and significant effect on poverty. This means an increase in economic growth of $1 \%$ will reduce poverty in the Regency / Municipality of North Maluku Province by $-0.661 \%$

This finding also supports the results of Sulistyowati (2013), demonstrating that the policy of increased education, health and infrastructure expenditure led to an increase in employment in all sectors and reduced poverty. 


\section{CONCLUSION}

Capital expenditure variable is an indicator of capital resource strengthening which has a positive and significant impact. This shows the implementation of development policies as outlined in capital expenditure on APBD, empirically considered good for regional macroeconomic goals, achieving regional economic growth so it needs to be further improved.

Capital expenditure allocation has a positive but insignificant effect on the Human Development Index. This indicates that the government should allocate capital expenditure funds, especially in the field of higher education, with the expectation for regional progress and educating the local child that is by way of building construction, facilities and infrastructure.

The allocation of capital expenditure has a positive and significant impact on poverty. This should allocate capital expenditures devoted to infrastructure development and local government programs should be more pro-local to impact on poverty reduction. While economic growth has a negative impact on poverty. Furthermore, Human Development Index (HDI) as an indicator of strengthening of human resources has a negative and significant influence on poverty level in 9 regencies of North Maluku Province.

\section{REFERENCES}

1. Barro, R. J., Sala-i-Martin. 2004. Economic Growth: 2nd Edition. London. England. The MIT Press Cambridge, Massachusetts

2. Danladi, J. D., Akomolafe, K. J., Olarinde, O. S., Anyadiegwu, N. L. (2015) 'Government Expenditure and Its Implication for Economic Growth: Evidence from Nigeria', 6 (18), pp. 142-151.

3. Hamsinah, H.J., Mursinto, D., Soekarnoto. 2014. Influence of Capital Expenditure to the Economic Growth and Manpower Absorption and People Welfare in Regencies / Cities in South Sulawesi. European Journal of Business and Management, Vol. 16: 1-5.

4. Nopiani, N. M., Cipta, W., Yudiaatmaja, F. 2016. The Effect of Local Original Income, General Allocation of Funds, and Capital Expenditure to Economic Growth. E-Journal Bisma Ganesha University of Education (Volume 4 of 2016)

5. Rahmawati, F. 2011. "The Influence of GDP, Life Expectancy, and Literacy Againsts Poverty Rate in the Central Java Province" Department of Economics and Development Studies UIN Jakarta.

6. Ranis, G. 2004. "Human Development and Economic Growth", Center Discussion Paper, No. 887, pp. 1-13.

7. Sasana, H. 2012. The Effect of Regional Government Expenditure and Per Capita Revenue on Human Development Index (Case Study in Central Java Province), Media Economicsand Management 25 (1).

8. Sulistyowati, N. 2013. The Expectation and Economic Growth in Nigeria, 1970-2008: A Disaggreegated Analysis, Business and Economics Journal. 2010: 1-10 of the Republic of Indonesia, Act No.32 of 2004 on Regional Government

9. Sumiyati, Eti, E. 2009. The Effect of Capital Expenditure on Increasing Human Development Index in West Java Province. Journal of Department of Management Faculty of Economics UNJANI

10. Tamboto, Morasa, L., L, Jenny Mawikere. (2014) 'Analysis of Local Financial Capability in the Period of Regional Autonomy in Southeast Minahasa District', Economic Journal, 2 (2303-1174), pp. 755-767.

11. Yani, A. 2002. Financial Relationship between Central and Local Government in Indonesia. Raja Grafindo Persada: Jakarta. 